$10-2016$

\title{
Book Review: Clan Cleansing in Somalia: The Ruinous Legacy of 1991
}

Rebecca M. Glade

University of Khartoum and Columbia University

Follow this and additional works at: https://digitalcommons.usf.edu/gsp

\section{Recommended Citation}

Glade, Rebecca M. (2016) "Book Review: Clan Cleansing in Somalia: The Ruinous Legacy of 1991," Genocide Studies and Prevention: An International Journal: Vol. 10: Iss. 2: 147-150.

DOI:

http://dx.doi.org/10.5038/1911-9933.10.2.1402

Available at: https://digitalcommons.usf.edu/gsp/vol10/iss2/16

This Book Review is brought to you for free and open access by the Open Access Journals at Digital Commons @ University of South Florida. It has been accepted for inclusion in Genocide Studies and Prevention: An International Journal by an authorized editor of Digital Commons @ University of South Florida. For more information, please contact digitalcommons@usf.edu. 
Book Review: Clan Cleansing in Somalia: The Ruinous Legacy of 1991

\author{
Rebecca M. Glade \\ University of Khartoum \\ Khartoum, Sudan \\ Columbia University \\ New York City, New York, USA
}

Clan Cleansing in Somalia: The Ruinous Legacy of 1991

Lidwien Kapteijns

Philadelphia, University of Pennsylvania Press, 2013

308 Pages; Price: \$29.95

Reviewed by Rebecca Glade

Columbia University, The University of Khartoum

At the beginning of Against Forgetting, Carolyn Forche quotes Bertolt Brecht to affirm that "In the dark times, will there also be singing? Yes, there will also be singing, about the dark times" underlining the importance of poetry, even in the midst of atrocity. ${ }^{1}$ This continues to be proven important; one cannot help but think of art produced in even the darkest of circumstances as bearing insight into the experiences of people within a society undergoing violence. Since the early 1990s when Against Forgetting was published, the study of poetry of witness has expanded, integrating into the broader body of literature on genocide and mass atrocity, with a general recognition that literature speaks to the intangible horror in a way that more analytical work will never fully grasp. So too do poetry and oral traditions reflect the feelings of diaspora, recording the ways that feelings and identities change over time and the ways that they endure. Rarely, however, does analysis begin with poetry, expanding then to a broader history of mass violence.

Kapteijns' Clan Cleansing in Somalia the Ruinous Legacy of 1991, whose research rests on a strong analysis of Somali literature, does just that. Examining Somali poetry, songs, publications, as well as interviewing key Somali officials on their time in the 1990s, Kapteijns provides an excellent account of the ethnically - or clan-based - violence that became so prevalent in Somalia in 1990 as the Siyad Barre regime collapsed. This account is significant because it discusses the clan-oriented nature of the violence frankly without subscribing to the fixed categories that leaders used to mobilize violence and provides important discursive links between the way that elites spoke and the changes in the nature of violence at that period. Most importantly, the book seeks a unified narrative for the violence, assigning responsibility to political figures for the discourse and the ensuing "clan cleansing" of 1990-1991.

Kapteijns's central focus began with a study of Somali discussions of this period, primarily in poetry and song, a focus that builds off of her previous work on Somalia. Looking at "prestigious poetry" that rises above clan audiences to speak to the larger Somali community, clan-oriented poetry that often addresses specific clan groups and pushes forward clan-hate narratives, and unconventional forms of Somali literature including contemporary poetry and novels by Somalis in diaspora, Kapteijns sheds light on ways that Somali artists discussed and failed to discuss violence from this period. Prestigious poetry, Kapteijns notes, is upfront in condemning the violence that occurred and the destruction of the state. Poets such as Mustafa Sheekh Cilmi, Axmad Naaji Sacad, Cabdi Muxumed Amiin, and Cabdulqaadir Cabdi Shube all denounce the violence in no uncertain terms, positioning themselves within a national Somalia that rejects divisions. At the same time, all of these poets shied away from discussing explicitly the nature of the problems in detailed terms, and all were careful to avoid pointing out who was responsible for such problems. While these poets imply that certain groups, such as the United Somali Congress (USC), a rebel group that eventually entered Mogadishu and overthrew Siad Barre's regime, were responsible, no groups are named explicitly, either in terms of politics or clan. On the other hand, clan-oriented poetry from

${ }^{1}$ Carolyn Forche, introduction to Against Forgetting: Twentieth-century Poetry of Witness, by Carolyn Forche, (New York:

W.W. Norton, 1993), 29.

Rebecca M. Glade, "Book Review: Clan Cleansing in Somalia” Genocide Studies and Prevention 10, 2 (2016): 147-150. @2016 Genocide 
this period speaks of the clans themselves, calling on listeners to perpetuate violence and promoting stereotypes regarding other clans. It is only in some unconventional literature, whether novels by Somalis in diaspora or the poetry of Somali-Canadian poet Mohamud Togane, that violence is discussed reflectively with reference to clan, with an acknowledgement of the relationship between the mass violence and clan hatred narratives that became so prominent in the early 1990s.

With these narratives and this polarization in mind, Kapteijns uses the next two sections to provide a historical narrative of the violence and collapse of the state that Somalia experienced from 1989 to 1991. This narrative takes us from the power dynamics at play in the late period of Siyad Barre's reign as president into the period of rebellion, where various rebel groups, most prominently the USC but including several others, armed themselves and sought to overthrow the regime. Somalia in the late 80 s, even before state collapse, was marked by extreme violence, and Barre's government was the first among many groups to encourage collective punishment against groups where certain members proved resistant to government rule. In addition to the violence seen in Hargeisa and Somaliland, such dynamics were at play in other large cities. At the same time, this violence was not just collective punishment-rather, the discourse changed, both within the Barre regime and later within rebel groups. Systemic inequalities had existed before, but fell along largely regional lines, with those centered in Mogadishu gaining more resources than those living elsewhere. In the late 80s, however, Barre's regime and rebel groups used collective blame and new hate narratives in order to mobilize mass violence on behalf of particular political causes. Thus, rebels intentionally conflated support of government with Darood identity and Hawiye identity with rebellion against the government, leading to massive, ethnically based violence that ultimately ignored almost entirely who had actually supported the regime and who had not.

The book concludes by discussing the implications of such discourse and the fracturing of Somali society that it prompted. Such changes were the result of what Kapteijns terms "clan hate mythologies," drawing on genocide literature regarding the ways that violent groups create justifications for violence that have their roots in particular interpretations of history. These histories often have basis in fact-for example, that certain groups might have more access to resources or more power, but require interpretation and the argument that such dynamics have created long-standing animosity in order to create a justification for violence where one had not existed previously. Historically, the Barre regime found its support through patronage networks that went along clan lines at times, although it traversed such divisions to find supporters who could be paid in other clans. Such complexity was obscured entirely by the discourse of clan hatred, and the violence that ensued was not centered around political issues but exclusively on clan. One of the ironies of the state collapse was that those in power did not shift entirely; rather, those who went on to take part in the next transitional government included prominent supporters of Barre, spared simply because they were Hawiye. On the other end, Kapteijns recounts an anecdote in which both a prominent supporter of Barre and an opponent of his regime lived next door to each other in a refugee camp in Kenya, both fearing for their lives because of their clan identity. ${ }^{2}$

Clan Cleansing in Somalia's stated goal-to name and make explicit the role that clan played during the disintegration of the state in Somalia - is important, and Kapteijns carries it out with the sensitivity and consideration necessary. Concluding that the term genocide is not particularly productive in the context of the Somali state's collapse, she nonetheless draws on a body of genocide literature regarding hate narratives and othering to create a greater understanding of the process by which armed groups who originally aimed their violence at an authoritarian state could turn to mobilizing mass violence against particular clans. She notes

Few are the scholars who critically examine the construct of clan rather than just accepting it, treating it as an unproblematic, 'natural' category, and attributing agency to it as if it were a single body or a machine operating automatically. Those who did refuse to take the concept of clan for granted successfully uncovered other principles of social and political organization and behavior...However, they-including the current author-mostly did not

${ }^{2}$ Lidwien Kapteijns, Clan Cleansing in Somalia The Ruinous Legacy of 1991 (Philadelphia: University of Pennsylvania Press, 2013), 141-142. 
engage how and under what circumstances clan as a feature of politics and society became a real historical political force. ${ }^{3}$

Kapteijns draws upon this paradox-on one hand, emphasizing the constructed nature of clan identity and the way that such identity change in the 1980s and 90s, while at the same time, showing how identity in 1990-91 was ultimately used as a bedrock for mobilization, proving more salient that previous political affiliations had been. As such, her analysis of 1989-1991 is particularly instructive in that it acknowledges the discourse heavy discussion of identity and its malleability without minimizing the importance of such constructs in the context of conflict.

Part of why this is possible is because of the source material drawn upon. Kapteijns undertook interviews with eye-witnesses to the violence and elites who were involved with resistance to the Barre regime; however, the bulk of her sources are songs and poetry from the period. As a result, the book seeks to draw essential links between the discourses prevalent at the time and the violence which occurred. Discourse analysis is used in many fields of social science and often draws out interesting truths about the nature of power relations and the ways that people conceptualize phenomena in their daily lives. It is far rarer for it to illustrate the mechanisms by which social movements and violence actually occur. In Clan Cleansing in Somalia, we not only see how the concept of clan is discussed, the ways elites and media makers spoke of clan, but also the results; the ways that elites used clan-related discourses to mobilize mass violence, ultimately at the expense of the populations that they claimed to represent, and the ways that this in turn led to alliances and reactions by the communities involved. Kapteijns notes "That the civilians of particular communities of victims initially sided with the USC or even participated in the clan cleansing campaign is an aspect that is often concealed by authors advocating for these groups... Pointing out that this was so does not excuse the injustice that was done to these communities but is a crucial analytical clarification of the different stages and contexts of Somali civil war violence." 4 Since the violence has continued in various forms until the present day, the discourses that are at the root of such communal violence take on greater weight. As Togane, a Somali-Canadian poet, concludes in his poem "Afweyne's Swansong," "That is why today/ MOGADISHU/ Our erstwhile capital of the Somali nation/Is clannish hell visible/ bearing Dante's invisible hellish inscription" ${ }^{5}$

In the process of drawing upon these strains of Somali history, Kapteijns manages to create a unified narrative that remains specific and assigns responsibility to particular political groups and elite figures of state and rebel actions. This sort of narrative, present for most other national histories (with some notable exceptions, all of which also face regular violence), is particularly important in the context of Somalia. Eugene Weber described in From Peasants into Frenchmen how nation-building requires both remembering and forgetting, so that in order for collective identities to function, society must be compelled to remember particular, unifying things while underplaying more divisive truths. ${ }^{6}$ The violence that ruptured the Somali state in 1990 and the ongoing violence, both clan-based and otherwise, has fundamentally fractured society, leading to remarkably little communication between different communities. Such fragmentation can even be seen online, where diaspora groups divide along clan lines, communicating in different chat forums and assigning responsibility to different figures. ${ }^{7}$ In this context, it makes sense that historical accounts, as well as the society at large, would be fractured, and in desperate need of common historic narratives, ones that are inclusive and seek reconciliation through accountability. Kapteijns's work then participates in the process of rebuilding Somalia, starting at the intellectual underpinnings of society, ones that can be used to reinforce and forge more positive communal identities. Her narrative allows

\footnotetext{
${ }^{3}$ Kapteijns, Clan Cleansing in Somalia, 73.

${ }^{4}$ Kapteijns, Clan Cleansing in Somalia, 203.

${ }^{5}$ Kapteijns, Clan Cleansing in Somalia, 68.

${ }^{6}$ Eugene Weber, Peasants into Frenchmen the Modernization of Rural France, 1870-1914 (Stanford: Stanford University Press, 1979).

${ }^{7}$ Abdisalam M. Issa-Salwe, "The Internet and the Somali Diaspora: The Web as a New Means of Expression," Bildhaan: An International Journal of Somalia Studies, 6 (2006) 54-67, accessed August 4, 2016, http://digitalcommons.macalester.edu/ bildhaan/vol6/iss1/8.
} 
Somalis to grapple with a violent past and acknowledge the divisions that have rent society for over twenty years, while also urging readers to lay aside their divisions by recognizing the role that elites on all sides played in fostering such divisions. By "remembering" the violence and the way that it was manufactured, even while "forgetting" the manufactured divisions, society can seek to forge new connections and rebuild itself even as southern-central Somalia pushes towards greater stability in the face of attacks by al-Shabab and other armed groups.

If anything seems to be lacking for this book, it would be only a community of scholarship that can contextualize the history that Kapteijns presents. Indeed, it is shocking how little work exists on the past twenty-five years of Somali history and how difficult it is to this day to gather information on a period so close to the present day. The same scholars repeat again and again in bibliographies about Somali history, not exclusively due to their quality, but also due to the impediments to studying this period and the limited number of people capable of doing so. Too often, the focus of scholarship on Somalia seems to be exclusively oriented towards the present and the most recent elements of the conflict there. Kapteijns states explicitly that her nine oral interviews should not be taken as a comprehensive look at what happened politically or socially during her period of study. Undoubtedly this is true and fair, but the fact that few examinations exist elsewhere today simply underscores how much needs to be discussed further. It seems that in the absence of a national archive, and in the absence of a stable state in which to conduct research, the barriers to careful, comprehensive research grounded in the personal experiences of Somalis became (at least in part) prohibitive, and little was put forward - although that is changing and one hopes this change continues.

It is now then that poetry takes on such great importance in the study of Somalia and Somali history. Yes, Somali poetry has long had great status in Somali society, and yes, its prestige is historical, with a rich oral tradition that only continues with the aid of mass media. And indeed, diasporas tend to value literature that brings them together and forge communities. Yet for Somalia, poetry stands out as a way to bind together a diaspora not without a center, but one with a center whose turbulence has made it difficult to reach, albeit increasingly less so in recent years. Poets and scholars write not really to bind a diaspora to the center, but to surround it, trying to reach a place whose reality was too difficult, too violent and unstable to inhabit directly for a long time. Kapteijns succeeds not only in discussing clan and violence in an innovative way, but also in touching upon this unreachable center, bypassing impediments that stifled so much work on Somalia. 